\title{
Capturing Multiple Intelligences Profiles of Muhammadiyah Junior High School Students
}

\author{
Iswan ${ }^{1}$, Herwina Bahar ${ }^{1}$, Misriandi $^{1}$, Agrissto Bintang Aji Pradana ${ }^{1 *}$ \\ ${ }^{1}$ Faculty of education, Muhammadiyah University of Jakarta, Indonesia \\ ${ }^{2}$ Department of Elementary Teacher Education, University of Muhammadiyah Magelang, Magelang, Indonesia \\ *Corresponding author. Email: agrisstobintang@ummgl.ac.id
}

\begin{abstract}
Multiple Intelligence Theory has been integrated in educational settings, including in ELT classrooms. Some scholars attempt to find the impacts of this theory. However, as a basic data in applying this theory, profiles of MI is required. This study is an attempt to describe students' MI profiles. It is conducted in Muhammadiyah Junior High School of Borobudur. 77 students of 8th grade is assigned as the sample. MI Inventory questionnaire adapted from Rogers' indicators is employed to obtain the data. The dominant and least intelligence are captured. Strength levels of each intelligence Aare also described quantitatively. Kinesthetic is the dominant and has the most frequency of strong level. While linguistic intelligence is the least. The results give English teachers reference to determine appropriate methods in ELT classroom activities.
\end{abstract} Keywords: multiple intelligences, Muhammadiyah, Junior High School

\section{INTRODUCTION}

A conducive learning environment (condition) system plays crucial roles in the effort to achieve learning objectives. This will relate to teaching. It is established by various components which support each other. They are learning goals, materials, teachers and students, activities, and facilities. A conductive learning atmosphere will promote students' participation and creativity. In this case, teachers may have greater roles to assist them reach the achievement. The current English curriculum demands a teaching and learning settings which enable students to communicate appropriately in oral and written texts for various purposes (e.g. building social relationships, and developing insights through information exchange). These objectives should not only be achieved through lectures and academic explanations but also attractive and explorative approaches. In accordance with this, teachers must already have a plan and determine strategies.

In determining and implementing strategies teachers should consider students' characteristics and their learning styles. English Language Leaning does not merely involve verballinguistic abilities as viewed in traditional intelligence concept. [1] views individuals possess their own strengths, weaknesses, personal features, and personality types. They also possess different types and levels of abilities to overcome problems called Multiple Intelligences (MI). It views that teaching strategies can be controlled by providing students options of how they will learn. Focusing on their own personal traits will encourage them to improve knowledge and skills. In line with it, teachers can refer to this theory to design classroom activities which provides various ways [2] and meaningful learning [3]. There are eight intelligences possessed by individuals [1] and the followings present their preferences of learning [4].

Verbal-linguistic intelligence involves ability to learn words and languages. Those who possess this intelligence are interested in telling stories, reading, writing, and playing word games. They are also engaged in activities using books, stories, poetry, author visits, etc.

Logical-mathematic intelligence involves ability to learning by questioning, experimenting, and calculating. Those who possess this intelligence are interested in logical reasoning. They are engaged in problem solving, exercises, or drilling activities.

Visual-spatial intelligence involves ability to design, draw, and visualize images. Those who possess this intelligence are interested in painting, drawing, photography, illustrating, and graphic design. They are engaged in activities using graphs, charts, posters, and other visual images.

Bodily-kinesthetic intelligence involves ability to control movements. Those who possess this intelligence are interested in dance, running, gesturing, jumping, building, and other physical movements. They are engaged in activities using movies, and rhythm exercises.

Musical intelligence involves ability to produce rhythm and melodies. They are interested in singing, listening, tapping feet and hands, and other rhythmic activates.

Interpersonal intelligence involves ability to respond others' mood appropriately. They are engaged in sharing, debating, working in group, and organizing.

Intrapersonal intelligence involves ability to access their own feelings. They are interested in activities related to their needs and goals, such as dreaming, planning, writing journals and telling about themselves.

Naturalist intelligence involves ability to overcome problems related to nature and natural forms. They are engaged in gardening, playing with pets, caring for animals and plants, and investigating nature.

Multiple Intelligence profile may impact the students' learning preferences, activities and outcome [5]. A number of studies reveals other positive impacts of Multiple Intelligences to learning achievement [6][7], motivation [8], and language proficiency [9-12]. In ELT practices, MI 
theory is integrated in through its methods [13][14] to enhance writing skills [7][9], grammar accuracy [12]. However, the first step in implementing Multiple Intelligences in classroom activities is identifying students' profiles. This is important since it become a start to carry out the learning activities or relate Multiple Intelligence to other educational practices. Some attempts are carried out to describe students' Multiple Intelligences [5][8][15-18]. Existential intelligence, interpersonal, and verbal-linguistic intelligences are mostly possessed by students [5]. [16] reveals verbal-mathematical and visual-naturalistic are the most frequent combinations. Logical-mathematic, verballinguistic, intrapersonal, and visual-spatial are the most possessed intelligences [17].

The above explanations show how Multiple Intelligences contribute to educational and language learning settings. Therefore, this study takes into account assessing students' types of Multiple Intelligences. It aims at describing their MI profiles. In line with that, there are questions to be answered as follows.

a. What is the dominant and least intelligence possessed by the students?

b. Research Question 2: In what levels are the intelligence possessed by the students?

This study gives educational implication as the results become references to implement MI theory in English Language Teaching.

\section{METHOD}

This study was conducted in Muhammadiyah Junior High School of Borobudur. 77 eighth grade students were assigned as the sample. They responded to a set of questionnaires namely Multiple Intelligences Inventory. It consisted of 80 statements adapted from Rogers' Indicators formed in Likert Type ranged from 1 to 4 . Score 1 indicates strongly disagree; 2 indicates agree; 3 indicates slightly agree; and 4 indicates strongly agree. Data were described quantitatively assisted with SPSS. To answer RQ1, the dominant intelligence was determined from the strongest one of each student. While all responses were classified into three categories, strong, moderate and weak to determine levels of the intelligence. In attempt to answer RQ 2, the following guideline was employed [19]:

Table 1 Category Guideline

\begin{tabular}{|cc|}
\hline Category & Criteria \\
\hline Strong & $\mathrm{M}+\mathrm{ISD}<\mathrm{X}$ \\
\hline Moderate & $\mathrm{M} \propto \mathrm{SISD}<\mathrm{X}<\mathrm{M}+\mathrm{SS}$ \\
\hline Weak & $\mathrm{X}<\mathrm{M}$ clSD \\
\hline
\end{tabular}

M: Mean

SD: Standard Deviation

\section{RESULT AND DISCUSSION}

RQ 1 requires a dominant and the least intelligence. The following is the distribution of the strongest one perceived by the students.
Table 2 The Strongest Intelligence of Each Students

\begin{tabular}{|c|c|c|c|c|c|c|c|c|}
\hline $\mathrm{N}$ & 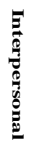 & 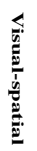 & 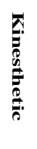 & '. & 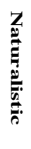 & 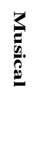 & 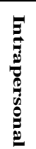 & 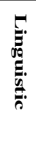 \\
\hline 77 & 10 & 8 & 24 & 5 & 13 & 15 & 2 & 0 \\
\hline
\end{tabular}

Based on Table 2, the dominant intelligence of all students is Kinesthetic (24 students) while Linguistic is considered to be the least (no student). The result is different from what [16] find that verbal-linguistic, logical mathematic, visualspatial, and naturalistic intelligences perceive the highest scores while musical intelligence perceives the lowest score. [5] also reveal different findings from the current study that Existential is the dominant followed by interpersonal intelligence and naturalist is the least frequent intelligence among others. Then a different finding is also stated by [17] that logical-mathematical is the dominant intelligence.

It means that $31 \%$ of class perceive characteristics of Kinesthetic intelligence who are interested in physical movements and engaged in activities using movies, and rhythm exercises. While characteristics of Linguistic intelligence do not appear in students' profile. There is no student who are extremely interested in telling stories, reading, writing, and playing word games or engaged in activities using books, stories, poetry.

RQ 2 requires levels of each intelligence perceived by each student. Descriptive statistics table is employed to find out the mean and standard deviation of the data. It involves all statements of eight intelligences. It is used to be a base to determine the score category.

Table 3 Descriptive Statistics

\begin{tabular}{|cc|c|c|c|c|}
\hline & N & Minimum & Maximum & Mean & Std. Deviation \\
\hline Number & 616 & 43 & 98 & 69.88 & 10.847 \\
\hline Valid N & 616 & & & & \\
\hline
\end{tabular}

According to Table 3, Data Mean is 69.88 and Standard Deviation is 10.847 . Then data are categorized using criteria in Table 1 into weak, moderate, and strong depending on the intelligences. The following is the distributions of frequency and category.

Table 4 Frequency Distributions

\begin{tabular}{|c|c|c|c|c|c|c|c|c|c|}
\hline & & 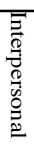 & 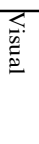 & 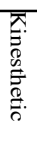 & 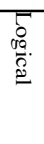 & 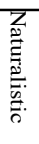 & 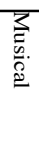 & 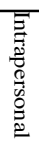 & 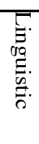 \\
\hline \multirow[t]{4}{*}{ Valid } & Weak & 6 & 6 & 0 & 25 & 10 & 14 & 11 & 30 \\
\hline & Moderate & 60 & 60 & 55 & 46 & 55 & 46 & 63 & 43 \\
\hline & Strong & 11 & 11 & 22 & 6 & 12 & 17 & 3 & 4 \\
\hline & Total & 77 & 77 & 77 & 77 & 77 & 77 & 77 & 77 \\
\hline
\end{tabular}

As shown in Table 4, Kinesthetic is the most frequent intelligence of strong level (22) followed by Musical (17), Naturalistic (12), Visual (11), Interpersonal (11), Logical (6), Linguistic (4), and Intrapersonal intelligence (3). The 
[2] M. Christison, A Guidebook for Applying Multiple Intelligences Theory in the ESL/EFL Classroom. Burlingame: Alta Book Center, 1999.

[3] E. Barrington, "Teaching to Student Diversity in Higher Education: How Multiple Intelligence Theory Can Help," Teach. High. Educ., vol. 9, no. 4, pp. 421434, 2004.

[4] T. Amstrong, Multiple Intelligences in the Classroom, 3rd ed. Alexandria: ASCD, 2009.

[5] N. Emmiyati, M. A. Rasyid, M. Asfah Rahman, A. Arsyad, and G. D. Dirawan, "Multiple intelligences profiles of junior secondary school students in Indonesia," Int. Educ. Stud., vol. 7, no. 11, pp. 103110, 2014.

[6] J. Safranj, "Logical/Mathematical Intelligence in Teaching English as a Second Language," in International Conference on Teaching and Learning English as an Additional Language, 2016, vol. 232, pp. $75-82$.

[7] Z. E. Gündüz and İ. D. Ünal, "Effects of Multiple Intelligences Activities on Writing Skill Development in an EFL Context," vol. 4, no. 7, pp. 1687-1697, 2016.

This study reveals the most frequent intelligence and captures strength level of each intelligence. English teachers should take account the students' personal traits in designing learning activities. Students have their own preference of learning. This is what teachers should know well. The findings can be considered as one of references to create conducive learning atmosphere in ELT classroom. Since it is only conducted in a small sample, capturing the dominant and strength level of intelligence, further research may take other areas such a greater sample and more specific language skills.

\section{ACKNOWLEDGMENT}

A big thank is addressed to English Education Depertment of Universitas Muhammadiyah Jakarta, Department of Elementary School Teacher Education of Universitas Muhammadiyah Magelang, and Muhammadiyah Junior High School of Borobudur for the supports. A gratitude is also delivered to LM3M of Universitas Muhammadiyah Magelang for the financial supports.

\section{REFERENCES}

[1] H. Gardner, Frames of Mind: The Theory of Multiple Intelligences. New York: Basic Books, 1985.
[8] M. Madkour and R. A. A. M. Mohamed, "Identifying College Students' Multiple Intelligences to Enhance Motivation and Language Proficiency," English Lang. Teach., vol. 9, no. 6, p. 92, 2016.

[9] K. Sadeghi and B. Farzizadeh, "The Relationship between Multiple Intelligences and Writing Ability of Iranian EFL Learners," English Lang. Teach., vol. 5, no. 11, 2012.

[10] L. Vakili, "The Relationship between Linguistic Intelligence and L2 Learning Strategies among EFL Learners with Intermediate Level of Proficiency," J. Lit. Lang. Linguist., vol. 1, pp. 89-93, 2013.

[11] E. Khodadady, "Logical-Mathematical Intelligence and Its Relationship with English Language Proficiency,” Am. J. Sci. Res., no. 89, pp. 57-68, 2013.

[12] R. Shayeghi and P. Hosseinioun, "The Relationship between Iranian EFL Learners ' Multiple Intelligences and Their Performance on Grammar Tests," Int. Sch. Sci. Res. Innov., vol. 9, no. 9, pp. 3066-3070, 2015.

[13] A. G. A. Ahmed, "The Relationship between Multiple Intelligences Theory and Methods of ELT," Int. J. Learn. Teach., vol. 4, no. 2, pp. 26-41, 2012.

[14] S. S. K. Ibnian and A. D. Hadban, "Implications of Multiple Intelligences Theory in ELT Field," ... J. Humanit. Soc. Sci., vol. 3, no. 4, pp. 292-297, 2013. 
Intelligence of Vocational Students in Application of Electric Energy Conservation,” J. Phys. Conf. Ser., 2017.

"Students' Logical-mathematical Intelligence Profile," J. Phys. Conf. Ser., 2018.

[16] G. Dolu and H. Urek, "A Study Related to the Investigation of Multiple Intelligence Profiles of Gifted and Talented Children across Turkey," J. Educ. Young Sci. Gift., vol. 2, no. 2, pp. 58-66, 2014.

[17] A. Kurniawan, N. Y. Rustaman, I. Kaniawati, and L. Hasanah, "Profile of Cognitive Ability and Multiple
[18] C. Dien and D. Wustqa, "The Interpersonal Intelligence Profile of Seventh-Grade Students in Mathematics Learning," J. Phys. Conf. Ser., 2018.

[19] S. Azwar, Penyusunan Skala Psikologi, 2nd ed. Yogyakarta: Pustaka Pelajar, 2012. 